\title{
Oxfordian brachiopods from the ammonitico rosso-type Fonyászó Limestone formation at Zengővárkony, Mecsek Mountains, Hungary and their palaeoecological, palaeobiogeographical and palaeopathological significance
}

\author{
László Bujtor ${ }^{1}\left[\right.$ : Richárd Albrecht ${ }^{2}$ (])
}

Received: 6 September 2020 / Accepted: 21 April 2021 / Published online: 28 June 2021

(c) The Author(s) 2021

\begin{abstract}
Recent discovery of a previously unknown outcrop in the vicinity of the Zengővárkony lime-kilns (Mecsek Mountains, Hungary) provided a few identifiable upper Oxfordian brachiopods that exhibit a truly Mediterranean (Tethyan) character. Dating of the outcrop is based on a rich ammonite fauna: Benetticeras benettii; Trimarginites ex gr. trimarginatus; Orthosphinctes (Orthosphinctes) ex gr. tiziani clearly indicate the Late Oxfordian. The brachiopod fauna indicates a deep-water marine environment and well-oxygenated sea floor. Nucleata bouei and Pygope catulloi are recorded for the first time from the Mecsek Mountains. A pathologic specimen of Pygope catulloi is also recognized. Its ventral valve was injured in an early developmental stage that caused deformation of the left side, which was overgrown by the healthy right side and created an asymmetric adult shell shape. Cause of the injury is unclear but it provides further evidence for subsequent healing of brachiopods after being injured. This is the first description and illustration of Oxfordian brachiopods from the Mecsek Mountains, Hungary. The occurrence of Tethyan originating pygopid brachiopods in the Oxfordian strengthens earlier observations that from the Bathonian/Callovian Tethyan influence became overwhelming in the Mecsek Mountains fauna. Pygope catulloi strengthens records from Algeria that pygopid brachiopods may have occurred very early on the periphery of the Western Tethys.
\end{abstract}

Keywords Upper Jurassic · Tethyan faunal elements · Pygopid brachiopods · Tisza tectonic unit · Mediterranean Faunal Province · Pathologic Pygope

\section{Introduction}

Upper Jurassic brachiopods from the Mecsek Mountains have been rarely reported, although upper Jurassic strata are well represented and have been known for almost 160 years (Peters 1862). A decade later, János Böckh carried out

Handlin Editor: Mike Reich.

László Bujtor

bujtor.laszlo.geology@gmail.com

Richárd Albrecht

albrechtrichard@mecsekerc.hu

1 Department of Geology and Meteorology, Institute of Geography and Earth Sciences, Faculty of Sciences, The University of Pécs, 6 Ifjúság útja, Pécs 7624, Hungary

2 Mecsekérc Ltd, 19 Esztergár Lajos utca, Pécs 7633, Hungary detailed mapping in the Zengővárkony region (between 1874 and 1878), and visited the lime-kilns of Várkony (today referred to as Zengővárkony). Böckh (1880: 18) reported a Pygope diphya from the Tithonian limestones of the abandoned quarry of Pusztafalu (today referred to as Zengóvárkony), but with neither a description nor figure. During the early 1910s, Elemér Vadász revisited these localities and summarized the knowledge in his monograph on the Mecsek Mountains (Vadász 1935). He recorded other Tithonian brachiopods (Terebratula cf. beskidensis (Zeuschner), Pygope diphya Catullo, P. janitor Pictet, and P. dilatata Catullo, but without giving a description, illustration or repository. He also reported previously unknown forms from upper Jurassic strata. According to Vadász (1935: 61), the beginning of the upper Jurassic sequence is characterized by cherty-shaly yellow limestones representing the upper part of the Oxfordian stage and listed the following brachiopods: 
Terebratula sp., Terebratulina cf. substriata Schlotheim. No figures were provided. Kimmeridgian brachiopods have not been reported from the Mecsek Mountains.

Even though upper Jurassic brachiopods of the Mecsek Mountains were known from faunal lists, many authors (Sandy 1988; Kázmér 1990, 1993; Somody 1992; Vörös 1993, 1997) used these works as references for palaeobiogeographical analyses. Vörös (1997) re-examined the old collection of the Mining and Geological Survey of Hungary and confirmed the presence of Tithonian brachiopods: Fortunella spoliata, Placothyris? carpathica, Pygope diphya, $P$. cf. janitor, and Zittelina sp., although only a line drawing of a Tithonian Pygope diphya from another locality in the Mecsek Mountains was included (Vörös 1997: 107, fig. 53). After a long period of referring to secondary data, Bujtor et al. (2020) commenced field work and collected, described and illustrated Tithonian (Pygope diphya) and Berriasian (Lacunosella hoheneggeri, Pygope janitor) brachiopods from the abandoned lime kiln at Zengővárkony, Mecsek Mountains. Rediscovery of the upper Jurassic-lower Cretaceous brachiopod and cephalopod fauna of the Mecsek Mountains resulted in the identification of previously unknown taxa and localities (Bujtor et al. under review).
Oxfordian brachiopods have not previously been described and illustrated from the Mecsek Mountains. The aim of this paper is to provide data on Oxfordian brachiopods collected from the Mecsek Mountains during July-August, 2020.

\section{Geological setting}

The Early Jurassic development of the Mecsek Mountains is characterized by shallow, coal-bearing clastic and marly sedimentation with a thick sandstone sequence that suggests a rapidly subsiding sedimentary basin. This basin is the northernmost part of a greater tectonic unit, the Tisza Mega-Unit (Fig. 1 herein; Haas and Péró 2004). This tectonic mega-unit is considered a microplate, that detached from the European margin (Vörös 1993; Csontos and Vörös 2004). Detachment brought remarkable changes in the sedimentation, which is recorded around the Bathonian/Callovian boundary, when pelagic sedimentation occurred in the Mecsek Mountains (Galácz 1984). This phenomenon is supported by recent tectonic results (Tari 2015): the opening Penninic (or Alpine Tethys) Ocean separated the Tisza Mega-Unit from the European margin during the Middle

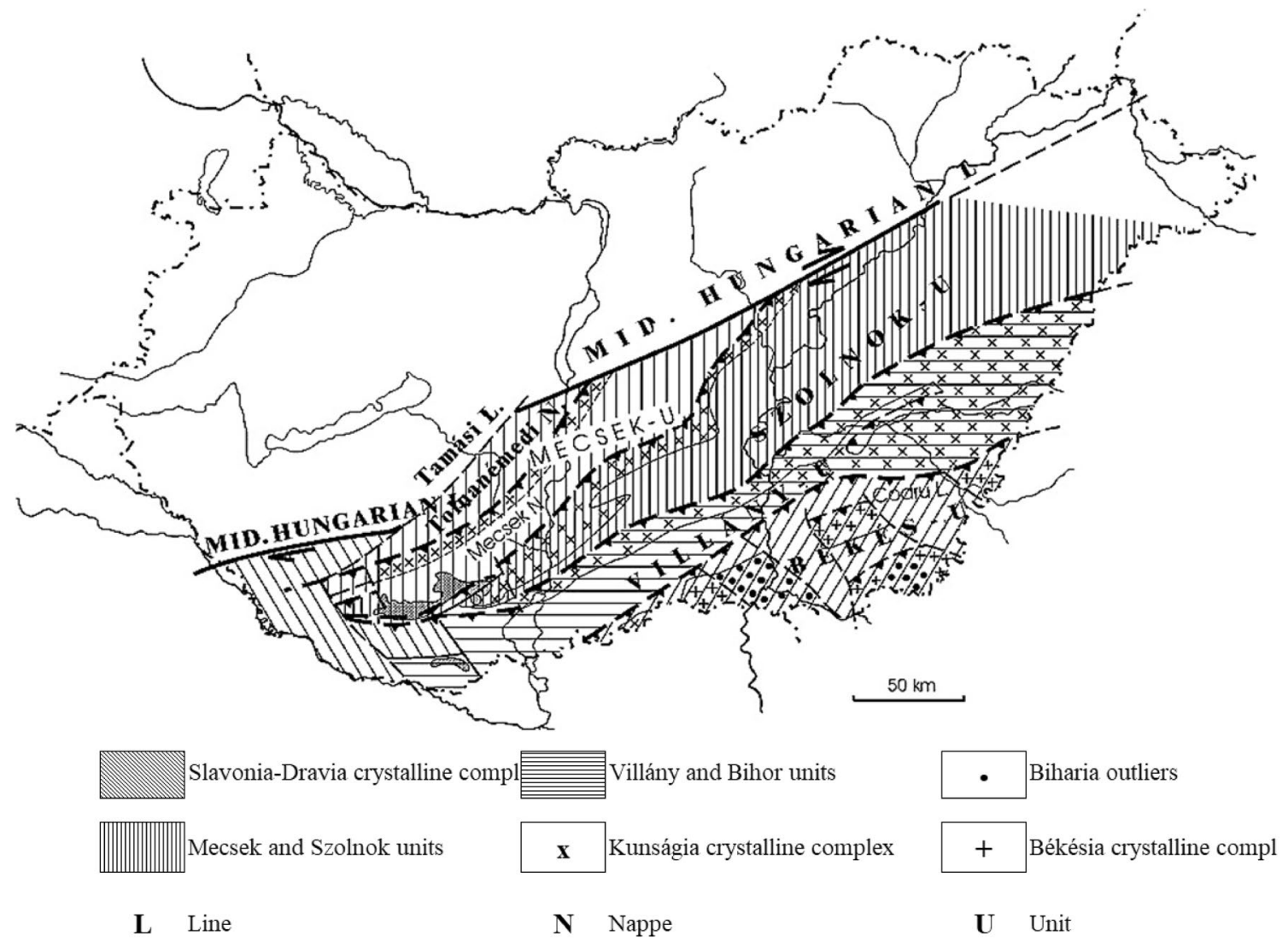

Fig. 1 Structural position of the Mecsek Mountains in the Mecsek Tectonic Zone of Hungary with indication of the major tectonic units. Map based on Haas and Péró (2004), simplified 
Jurassic. The separation brought Tethyan conditions to the Mecsek Mountains. This pelagic sedimentation resulted in ammonitico rosso-type nodular marly limestones (Raucsik in Főzy 2012) of Bathonian age being the most characteristic formation of the Middle Jurassic of the Mecsek Mountains (Óbánya Limestone Fm.). Later, the pelagic limestone sedimentation continued through the whole upper Jurassic (Fig. 2a). This significant change is reflected in the ammonite faunas, too. Géczy (1984: 388) noted that the ratio of the Phylloceratina and Lytoceratina taxa is around 5-10\% altogether in Lower Jurassic strata, while it significantly increases to $75 \%$ during the Bathonian/Callovian (Galácz 2015). According to Géczy, this significant change in the faunal composition is related to continuous subsidence, sealevel change and the formation of a pelagic basin that was invaded by the bathypelagic ammonites in the Middle Jurassic. This scenario is widely accepted by Hungarian geologists (Császár et al. 2013; Csontos and Vörös 2004; Galácz 2015; Haas and Péró 2004; Vörös 1993, 1995), however, the ammonite faunas of the Mecsek Mountains were neglected for decades with no primary ammonite faunal data available to support this approach. Although upper Jurassic ammonite bearing strata are known in the Mecsek Mountains for more than 150 years, systematic descriptions and quantitative analysis has just started (Bujtor et al. subm.). What we know for the moment is that both earliest Callovian (Galácz 2015) and earliest Valanginian (Bujtor 1993) ammonite faunas are dominated by phyllo- and lytoceratid ammonites that may have lived in an open, bathyal basin dominated by abundant Tethyan ammonites with some Submediterranean influence,

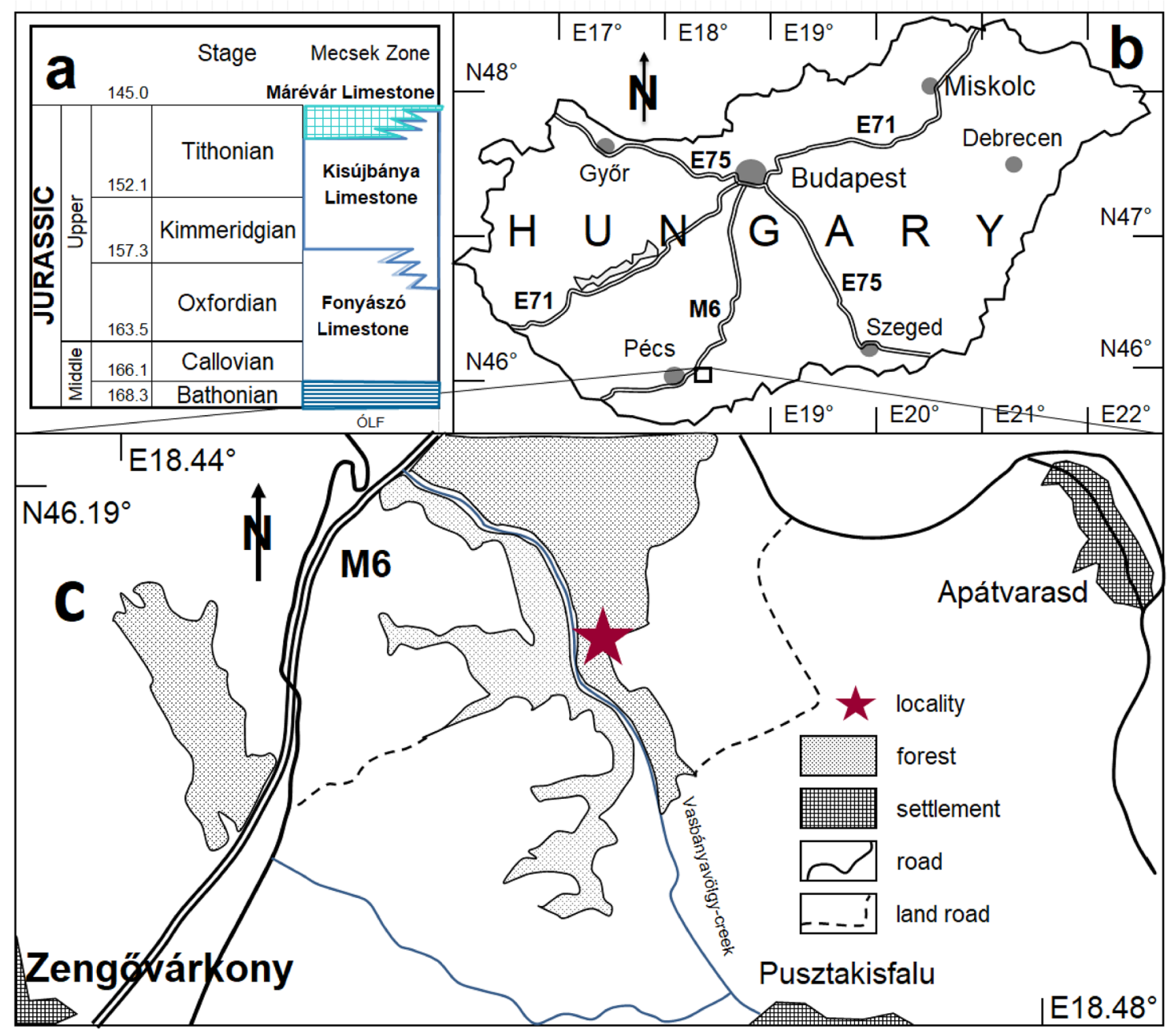

Fig. 2 Locality map and lithostratigraphic subdivision of the upper Jurassic-lower Cretaceoues (pars) strata mentioned in the text. a Lithostratigraphy of the Mecsek Zone for this study. Numerical ages after Cohen et al. (2013). Abbreviations. FLF Fonyászó Limestone Fm, KLF Kisújbánya Limestone Fm, MLF Márévár Limestone Fm, ÓLF Óbánya Limestone Fm. Lithostratigraphic units after Főzy
(2012), simplified. b Simplified map of Hungary. Black rectangle indicates the study area. c The Zengővárkony area indicating the surroundings of the abandoned quarry. Asterisk indicates the locality on the left (=Eastern) bank of the Vasbányavölgy creek in the Zengővárkony forest 
which is also reflected in the Callovian brachiopod fauna of the Mecsek-Villány Tectonic Units as well (Vörös 1990).

\section{Studied section}

The studied section is a natural outcrop discovered in July, 2020 in a secluded erosional gully and situated in the Eastern Mecsek Mountains (Fig. 2b), 25 km from Pécs in and close to the edge of the Zengóvárkony forest, NE from the lime kilns (Fig. 2c). Geological maps (Hetényi et al. 1968) did not indicate the outcrop. This is far from known tourist roads, the Vasbányavölgy-creek and hidden in a small depression (Fig. 3). The section is $1 \mathrm{~m}$ thick, and $5 \mathrm{~m}$ in length along strike; strike and average dip $305^{\circ} / 40^{\circ}$. The lower part is a thick unstratified, massive, white limestone bank of $46 \mathrm{~cm}$ thickness with occasional red mottling. There are three ammonite specimens per square meter on average on the upper weathered surface of the limestone bank. Although there were large-sized weathered ammonites (Fig. 3b) on the surface of the limestone bank, it was impossible to take out them. On top of the limestone bank is a nodular, unstratified marly red limestone with a very rich but poorly preserved ammonite content (ca. 250 ammonite specimens were collected along with four brachiopods). This bed is $40 \mathrm{~cm}$ thick (Fig. 3c). The fauna includes ammonites, aptychi, belemnites, brachiopods, and rarely bivalves, crinoids and echinoids. The presumed upper and lower continuation of this sequence is obscured by soil and debris.

Oxfordian strata around Zengôvárkony have been recorded as a thin, characteristic limestone bank of $1 \mathrm{~m}$ maximum thickness (Böckh 1880; Nagy 1964, 1971; Fôzy 1993). The lithostratigraphic column of the upper Jurassic around Zengővárkony is detailed in Fig. 4 (after Nagy 1964). Having discovered this section, our opinion is that the Oxfordian must be much thicker (taking into consideration that other ammonites referring to middle Oxfordian) around Zengővárkony, however, further field work is needed to find other Oxfordian outcrops and correlate them.
Fig. 3 Upper Oxfordian outcrop in the Zengóvárkony forest. a Limestone bank with $40^{\circ}$ dipping, thickness $46 \mathrm{~cm}$. b Large, weathered ammonite on the surface of the limestone bank. c Whorl fragment of an ammonite on the surface of the limestone bank. d Ammonitico rosso-type lithology—nodular, poorly stratified marly limestone that yielded a rich ammonite fauna comprises mainly lytoceratids and aspidoceratids. Coordinates: $46.1854^{\circ} \mathrm{N} ; 18.4592^{\circ} \mathrm{E}$
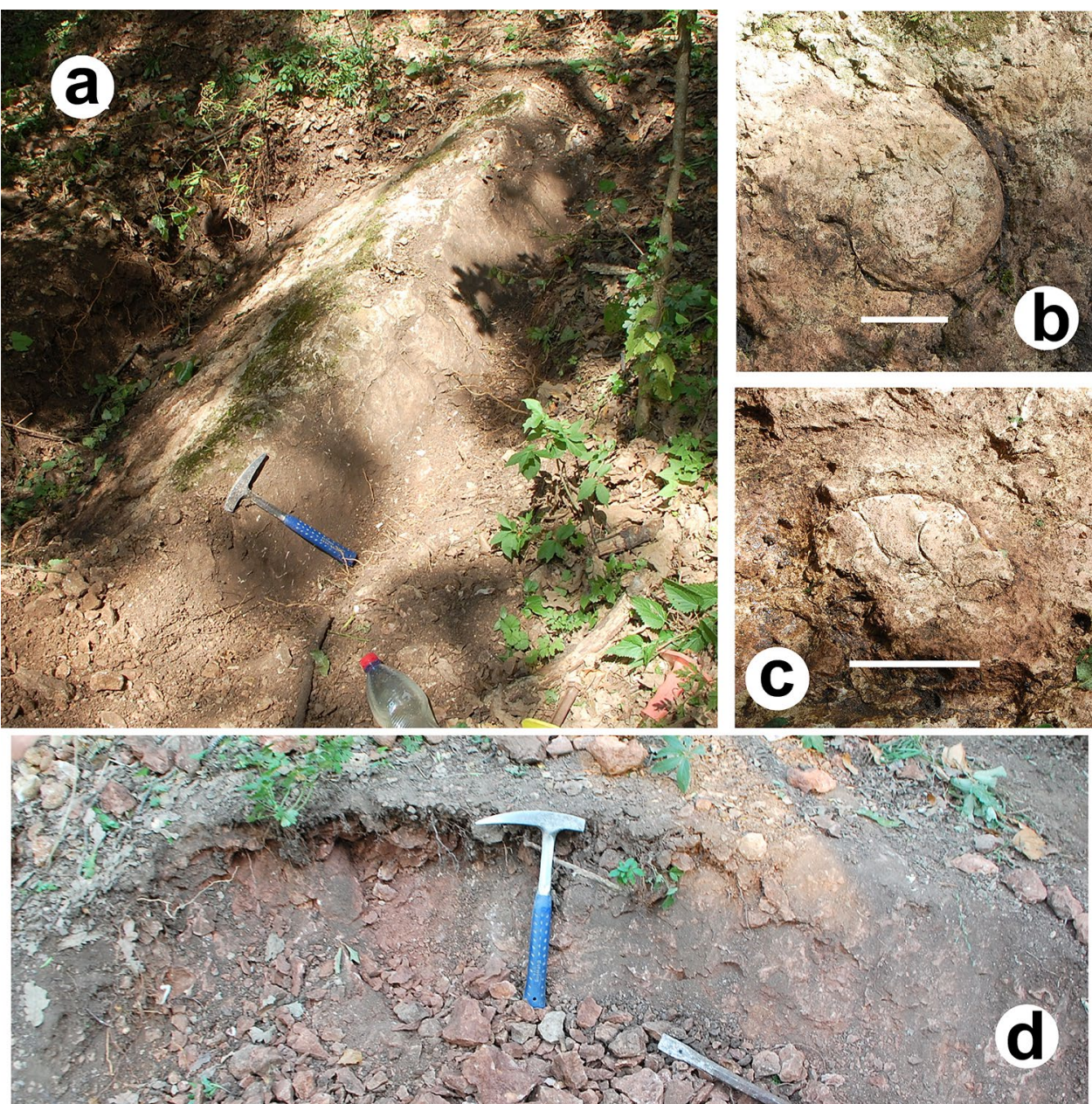
Fig. 4 The upper Jurassiclower Cretaceous section at Zengővárkony, Mecsek Mountains traversing the abandoned quarries. Lithological column after Nagy (1964), simplified with solid bar indicating the stratigraphic position of the brachiopods included in this study. Legend: (1) light coloured yellowish-grey thick bedded limestone; (2) thin bedded limestone; (3) marlyclayey, red coloured, patchy and nodular limestone; (4) light coloured yellowish-grey, thick bedded limestone; (5) light coloured yellowish-grey brecciated limestone with light grey flint nodules; (6) yellowishwhite brecciated limestone; (7) brownish-yellow clayey limestone. Chronostratigraphic subdivision of the section is based on micropaleontological investigations of Nagy (1964)
LITHOLOGY

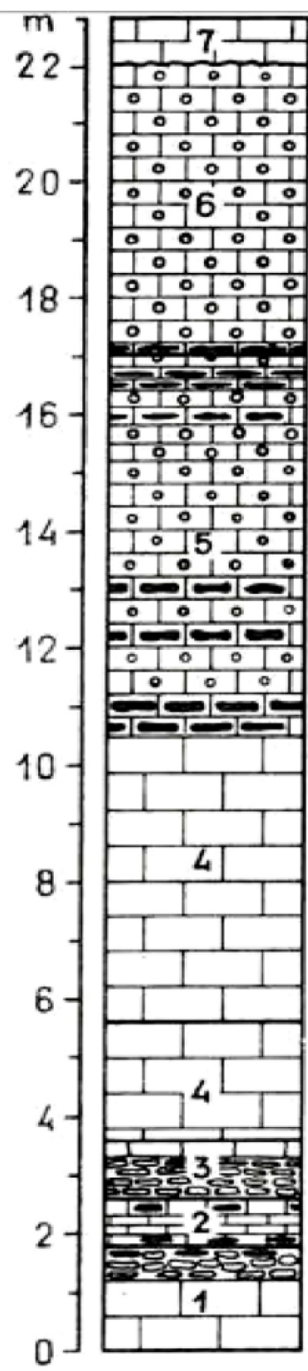

CHRONOSTRATIGRAPHY

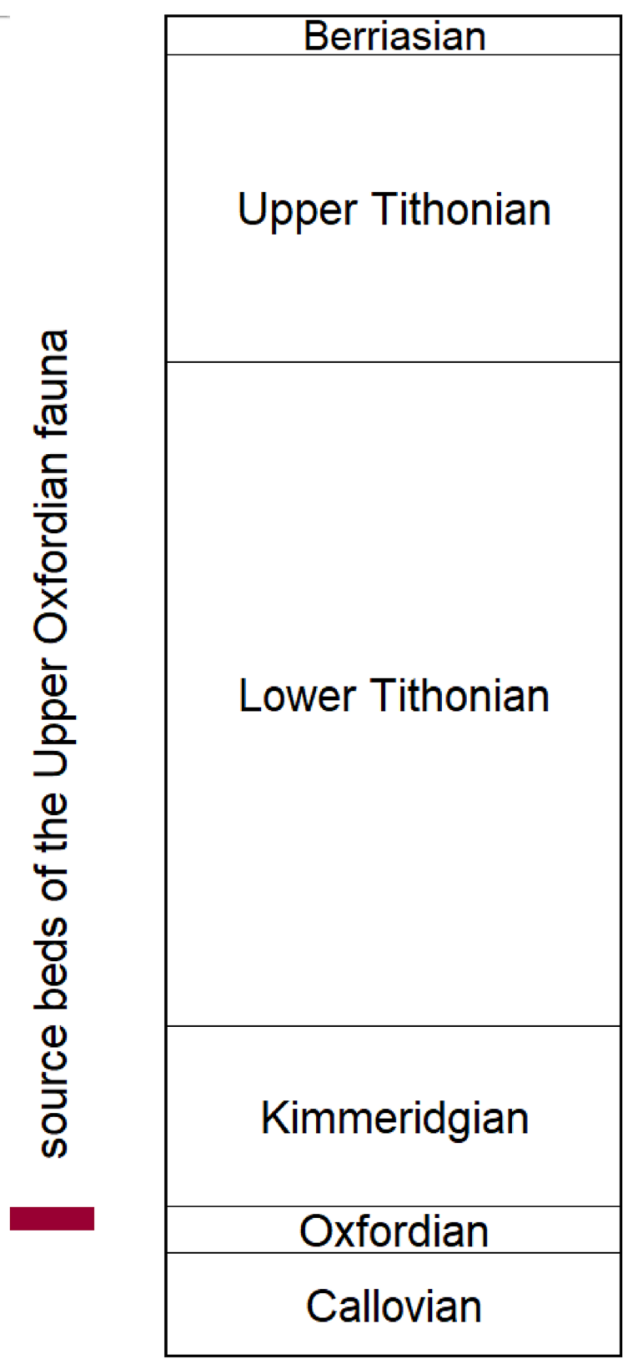

FORMATIONS

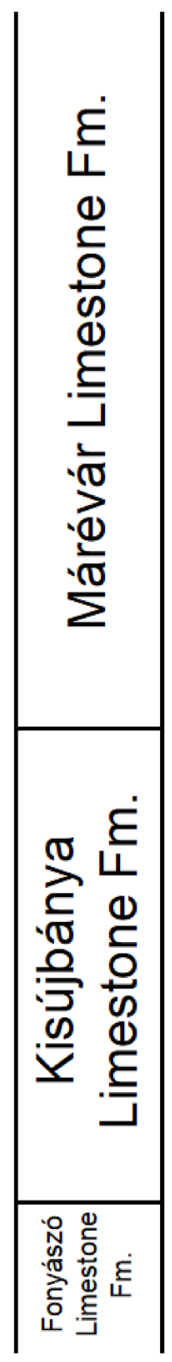

\section{Materials and methods}

Abbreviations. FO: First occurrence; L: Length of the valve; W: Width of the valve; $\mathrm{H}$ : Height of the valve; vp: Length of the perforation on the ventral valve; dp: Length of the perforation on surface of the dorsal valve according to Lukeneder (2002). Dimensions are given in mm. Measurements were acquired by a manual caliper. Photographs were taken with a Nikon D3500 DSLR camera. Measurements in brackets refer to estimated data due to poor preservation. The specimens are housed under ' $\mathrm{J}$ ' prefix in the Palaeontological Collection of the Mining and Geological Survey of Hungary, Budapest (abbreviated as MBFSz).

\section{Systematic palaeontology}

Phylum Brachiopoda Duméril, 1806

Subphylum Rhynchonelliformea Williams, Carlson, Brunton, Holmer, and Popov, 1996

Class Rhynchonellata Williams, Carlson, Brunton, Holmer, and Popov, 1996

Order Terebratulida Waagen, 1883

Suborder Terebratulidina Waagen, 1883

Superfamily Discolioidea Fischer and Oehlert, 1891

Family Nucleatidae Schuchert, 1929

Genus Nucleata Quenstedt, 1868 [= Glossothyris Douvillé, 1879; Vjalovithyris Tchorzhevsky, 1989]

Type species. Terebratulites nucleatus von Schlotheim, 1820. 
Nucleata bouei (Zeuschner, 1846)

Figures 5, 6

1846 Terebratula bouei Z.-Zejszner: 27, pl. 3, fig. 1.

1860 Terebratula Bouei Zeuschn.-Oppel: 167. [in lit.]

1870 Terebratula Bouéi Zeuschner-Zittel: 131, pl. 13, figs. 15-21.

1875 Terebratula Bouei, Zeuschner-Favre: 53, pl. 7, figs. 13-15.
1877 Terebratula Bouei, Zeuschner-Favre: 77, pl. 9, figs. 10-12.

1880 Terebratula Bouei Zeuschner-Coquand: 206. [in lit.] 1890 Pygope Boиei Zeuschner-Toucas: 586, pl. 14, fig. 9a, b. 1960 Pygope bouéi Zeuschn.-Fülöp et al.: pl. 4, fig. 2.

1962 Glossothyris bouei Zeuschner-Jarre: 93, pl. J, fig. 10a, b.

1977 Glossothyris bouei (Zeuschner)-Sequeiros: 9, fig. 3.1a-c.

1983 Nucleata (?) ex gr. bouei (Zeuschner)—Lobatscheva: 201, pl. 1, fig. 1 .
Fig. 5 a-f Nucleata bouei (Zeuschner, 1846)-upper Oxfordian, Zengővárkony, Mecsek Mountains, Hungary; specimen J 2020.86.1. a Dorsal view; b ventral valve; c posterior view; d-e lateral views; $\mathbf{f}$ anterior view. Scale bar indicates $1 \mathrm{~cm}$
Fig. 6 a-f Nucleata bouei (Zeuschner, 1846) - upper Oxfordian, Zengővárkony, Mecsek Mountains, Hungary; specimen J 2020.592.1. a Dorsal view; b ventral valve; c posterior view; $\mathbf{d}-\mathbf{e}$ lateral views; f anterior view. Scale bar indicates $1 \mathrm{~cm}$
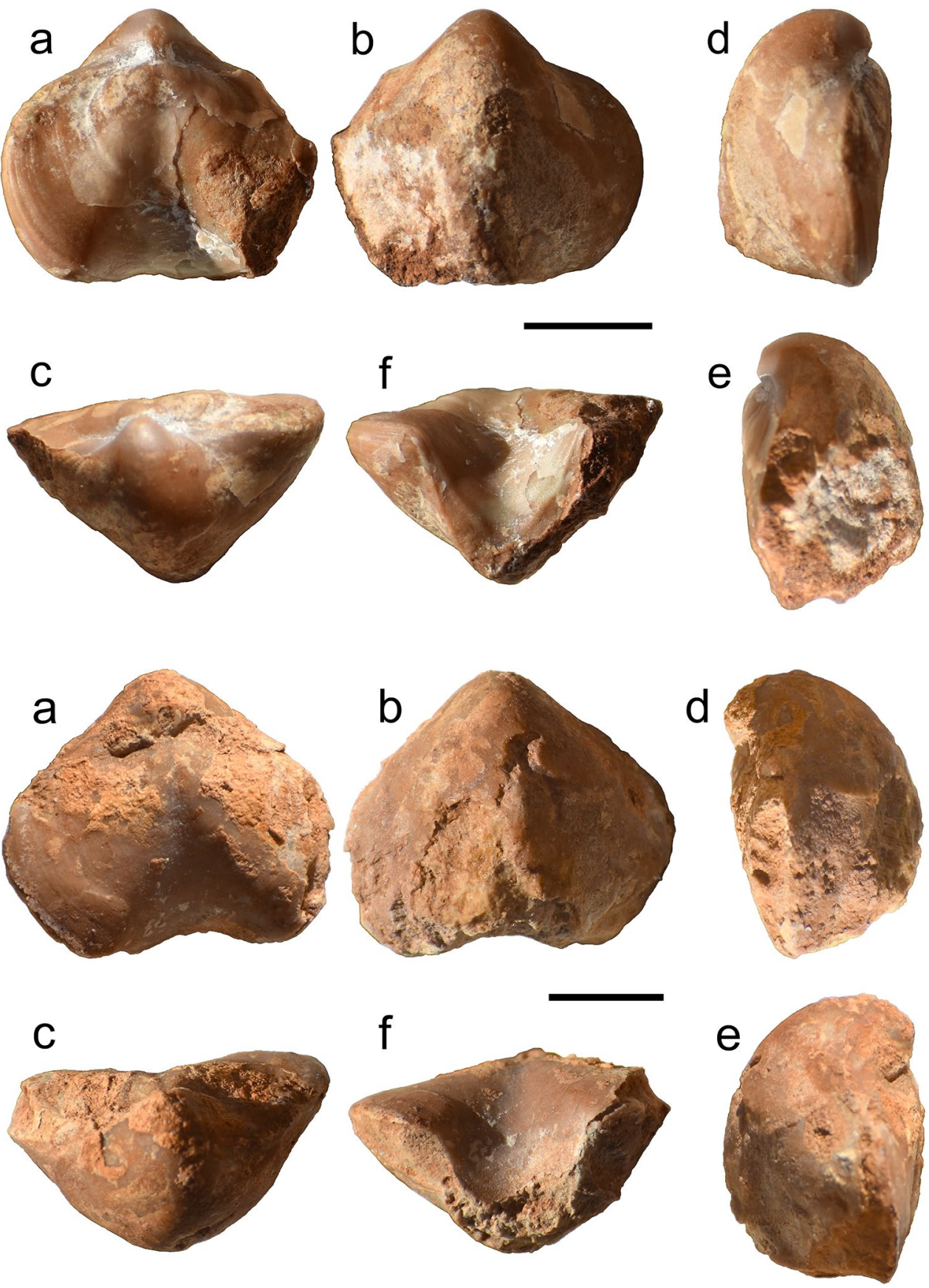
1993 Nucleata ex gr. bouei/planulata (Zeuschner)—Manceñido: 193 , fig. $1 \mathrm{f}-\mathrm{j}$.

1994 Nucleata bouei (Zejszner)—Mišík et al.: 261. [in lit.] pars 2016 Nucleata ex gr. bouei/rupicola-Sulser: 401, fig. 8 p.

2019 Nucleata bouei (Zejszner)-Vörös et al.: 7, fig. 5.15-16.

2020 Nucleata bouei Zejszner-Vörös et al.: 9, fig. 5.23a-b.

Material. Two fairly well preserved, partly decorticated specimens from red, ammonitico rosso-type upper Oxfordian limestone at Zengővárkony.

\section{Dimensions.}

\begin{tabular}{llllll}
\hline Specimen no. & $L$ & $W$ & $T$ & $W / L$ & $T / L$ \\
\hline J 2020.86.1 & 20.6 & 23.5 & 13.6 & 1.14 & 0.66 \\
J 2020.592.1 & 23.1 & 27.2 & 15.9 & 1.18 & 0.69 \\
\hline
\end{tabular}

\section{Description.}

External characters-Medium-sized Nucleata with subpentagonal outline. Anterior commissure unisulcate. Beak short, truncated by small, circular foramen. Dorsal valve sculptured by fine growth lines preserved on shell and internal mould, too. Ventral valve flattens in profile, fold gently elevated above anterior commissure, not sculptured except for the early growth stage around the umbo. Lateral commissure weakly S-shaped.

Internal characters-Serial sectioning was not performed due to the paucity of the material (only two specimens).

Remarks. There are three contemporaneous Nucleata species with similar shape and stratigraphic distribution: $N$. bouei, $N$. nucleata, and $N$. rupicola. The reliable separation of the species is based on biometry (after Sequeiros 1977: fig. 2): $N$. bouei is characterized by W/L ratios between 0.95 and 1.35 and $\mathrm{T} / \mathrm{L}$ ratios between 0.65 and 0.85 . The present specimens fit into this range. Toucas (1890: pl. 14, fig. 9) described only dorsal and ventral views, therefore the commissure cannot be observed. The present specimen belongs to the large-sized variety of the species and its dimensions are identical to that of specimen A1 of Zittel (1870) from Rogoznik (1870: 131): $L=20 \mathrm{~mm} ; W=23.5 \mathrm{~mm}$; $T=13 \mathrm{~mm}$. Vörös et al. (2020: fig. 5.23) described samesized specimens from the Berriasian of the Bakony Mountains (Hungary). It is the closest to the specimen of Favre (1877: pl. 9, figs. 10-12). First record from the Mecsek Mountains.
Stratigraphic and geographic distribution. The species has a wide stratigraphic distribution from the middle Oxfordian (Algeria: Coquand 1880) to the upper Tithonian (Poland: Barczyk 1991) or Berriasian (Lobatscheva 1983). New data (Vörös et al. 2020) suggest that it ranged even to the lower Valanginian. Geographically, it is distributed in the entire Tethys, both Mediterranean (Algeria; Bakony Mountains, Hungary; Tirol, Italy; Serbia) and Submediterranean Provinces (Subbétic Cordilleras, Spain; Ardéche, SE France; Switzerland; Rogoznik, Pieniny Klippen Belt, Poland; Crimea) and even into the Indo-Malagasy (Ethiopia: Basse 1930; Sula Islands, Indonesia: Manceñido 1993).

Family Pygopidae Muir-Wood, 1965

Subfamily Pygopinae Muir-Wood, 1965

Genus Pygope Link, 1830 [=Antinomia Catullo, 1851]

Type species. [pars] Terebratula antinomia Catullo, 1827.

Pygope catulloi (Pictet, 1867)

Figures 7, 8

pars 1827 Terebratula antinomia nob.-Catullo: 169, pl. 5, fig.t.

1867 Terebratula Catulloi-Pictet: 202. [in lit.]

1962 Pygope catulloi Pictet-Jarre: 58, pl. D, figs. 4a, b, 5, 6a, b, 9; pl. E, fig. 2a-d.

1963 Pygope catulloi (Pictet)-Thieuloy: 286, pl. 2, fig. 2; text-fig. 1.

pars 1964 Pygope dilatata (Catullo)—Fülöp: pl. 12, figs. 2a, b, $4 \mathrm{a}, \mathrm{b}$.

1966 Pygope catulloi-Vogel: 38, pl. 39, fig. 3; text-fig. 1.

1981 Pygope catulloi (Pictet)—Dieni and Middlemiss: 32, pl. 1, fig. 5; pl. 2, figs. $1-5$; pl. 3, figs. $1-3$; pl. 4, fig. 1 ; text-fig. 4.

1988 T. catulloi Pictet-Tubbs and Smith: 373. [in lit.]

1996 Pygope catulloi-Michalík: 177, fig. 3.9.

2002 Pygope catulloi (Pictet)-Lukeneder: 37, pl. 1, figs. 1-4; pl. 2, figs. 1-3.

2007 Pygope catulloi (Pictet)_Vörös and Dulai: 66, pl. 3, fig. 28a, b.

2010 Pygope catulloi (Pictet)—Benzaggagh et al.: 304. [in lit.]

2019 Antinomia catulloi (Pictet)—Vörös et al.: 7, fig. 5.8-10.

2020 Antinomia catulloi (Pictet)—Vörös et al.: 9, figs. 5.12a, b, 5.21a, b. 
Fig. 7 a-f Pygope catulloi (Pictet, 1867) - upper Oxfordian, Zengővárkony, Mecsek Mountains, Hungary; specimen J 2020.591.1. a Dorsal view; b ventral valve; c posterior view; d-e lateral views; $\mathbf{f}$ anterior view. Scale bar indicates $1 \mathrm{~cm}$

Fig. 8 a-e Pygope catulloi (Pictet, 1867) — upper Oxfordian, Zengővárkony, Mecsek Mountains, Hungary; specimen J 2020.593.1. a Dorsal view; b ventral valve; $\mathbf{c}-\mathbf{d}$ lateral views; e anterior view. Scale bar indicates $1 \mathrm{~cm}$
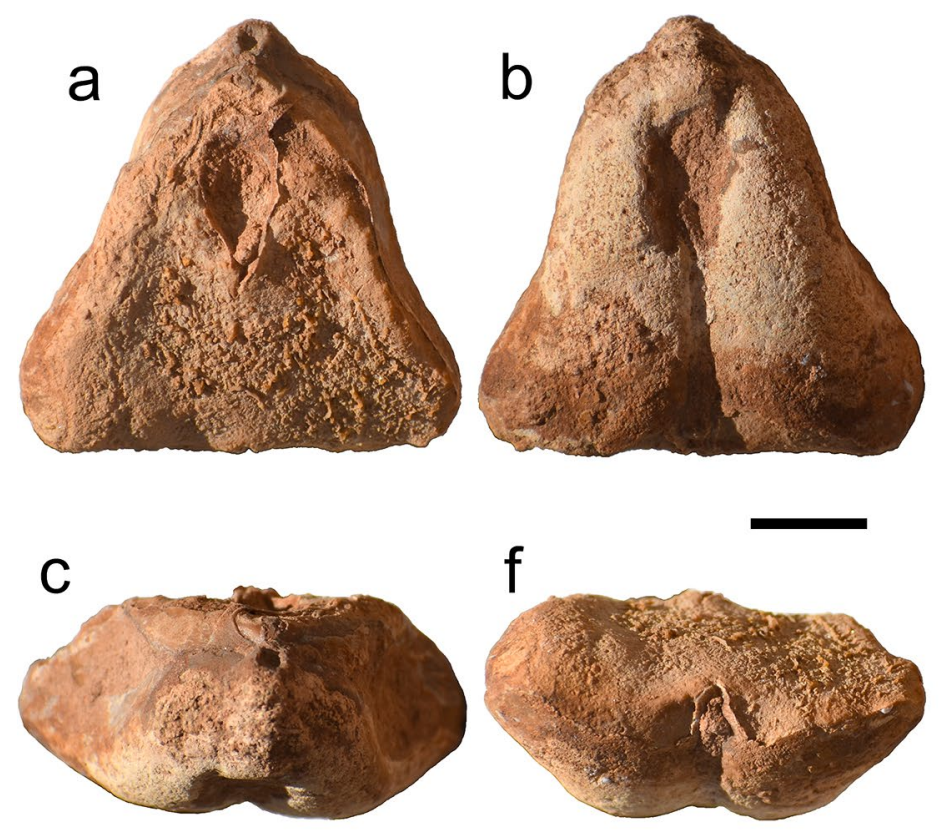
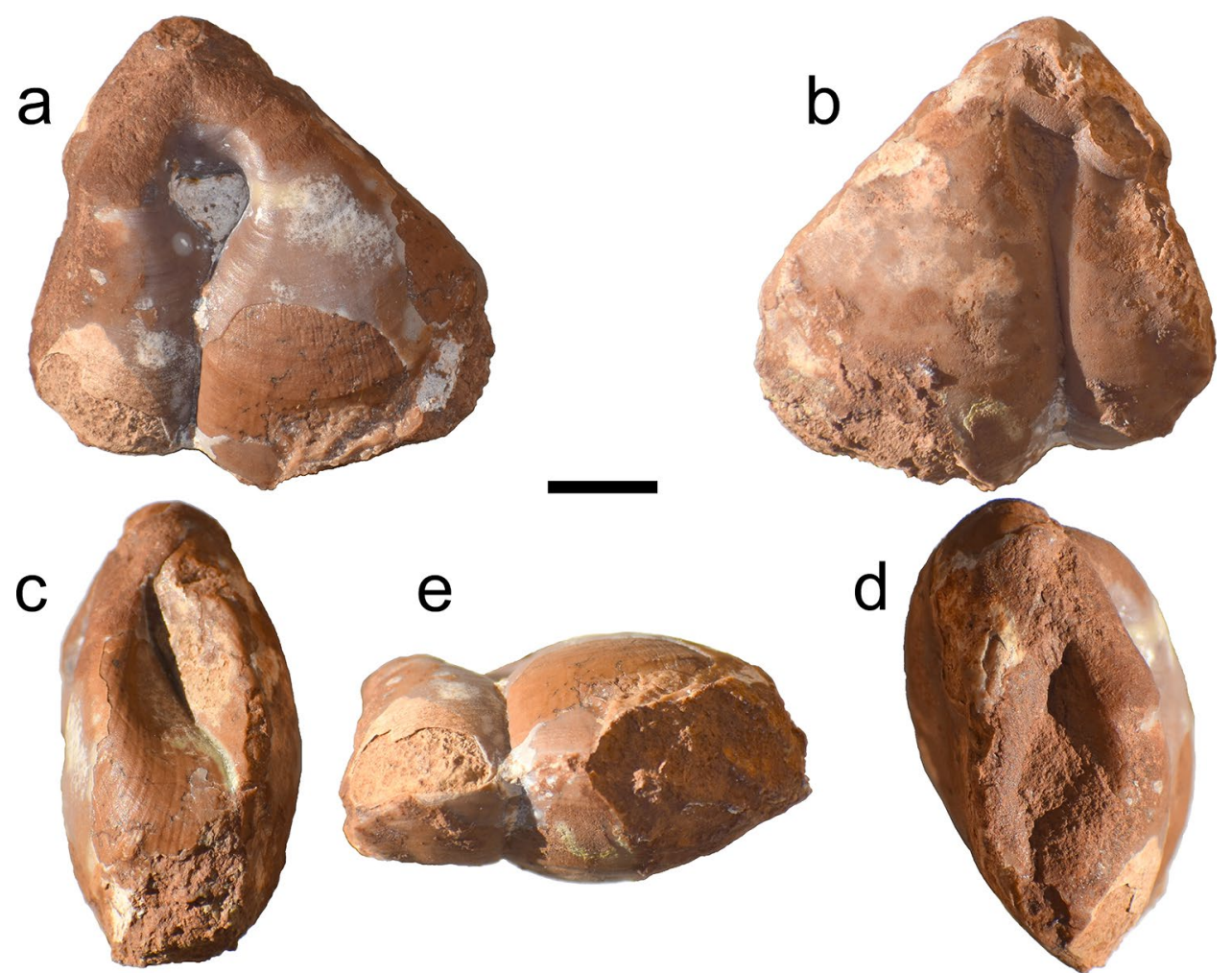

e

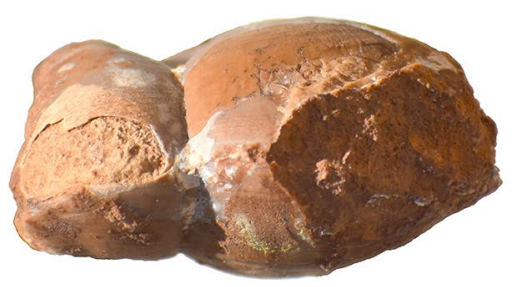

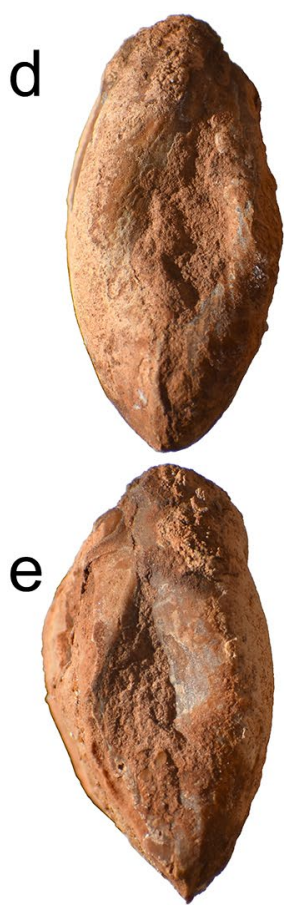

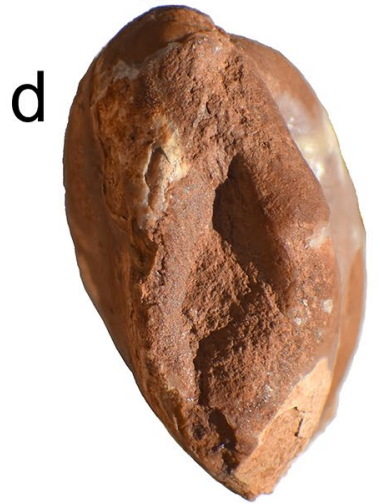




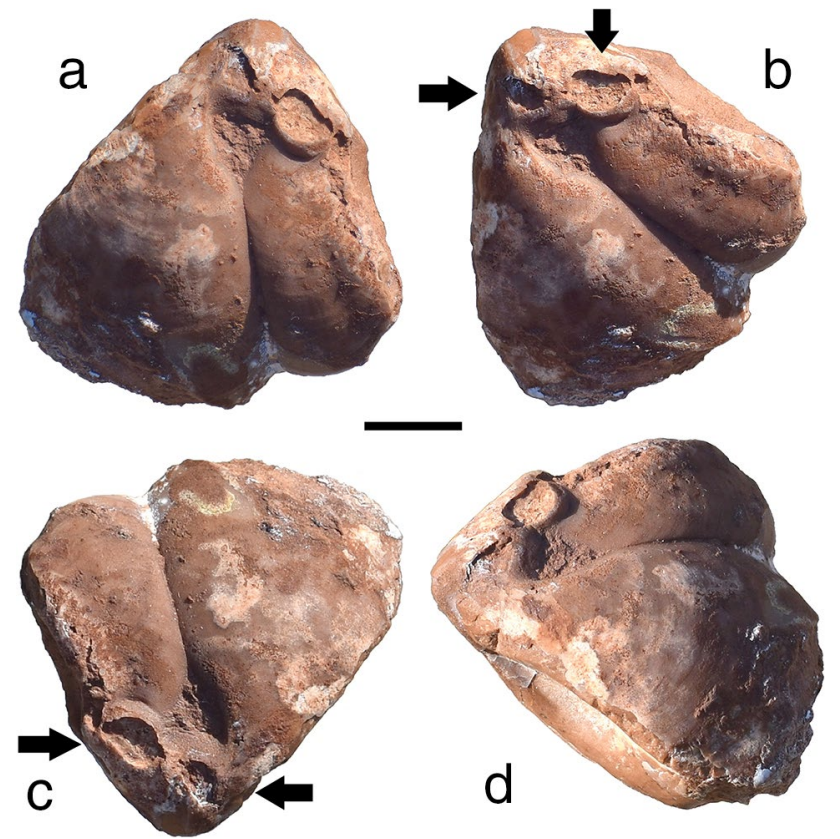

Fig. 9 a-c Close-up view of the injury on a Pygope catulloi (specimen J 2020.593.1) from upper Oxfordian ammonitico rosso-type limestone at Zengővárkony. The injury was not lethal, however, caused serious growth defect. Arrows indicate the injuries, which could best interpret as a bite mark only on the ventral valve and the bigger breakage could have hurt the epithelium causing significant growth deficiency. The healthy side of the valve outgrew the deformed side, the symmetry plane of the valve is distorted. Scale bars indicate $1 \mathrm{~cm}$

Material. Two decorticated, worn internal moulds from ammonitico rosso-type upper Oxfordian limestone bed at Zengővárkony.

\section{Dimensions.}

\begin{tabular}{llllll}
\hline Specimen no & $L$ & $W$ & $H$ & $\mathrm{vp}$ & $\mathrm{dp}$ \\
\hline J 2020.591.1 & 36.7 & 36.9 & 19.4 & $(9)$ & $(11)$ \\
J 2020.593.1 & 43.1 & 41.7 & 22.2 & $(6)$ & $(11)$ \\
\hline
\end{tabular}

\section{Description.}

External characters-Small-to-medium sized, slightly corroded, biconvex Pygope representing adult stage. Ventral valve triangular, dorsal valve bell or triangular shaped. Beak short, truncated by small, circular foramen. Umbo erected. Dorsal perforation comparatively large and teardrop shaped. Ventral perforation also comparatively large, tear-drop shaped. Perforation tube not seen. Ventral apical fold bold, pronounced, however poorly preserved and slightly corroded. Dorsal apical sulcus corroded, not seen. Lateral commissure sinuous. Anterior commissure corroded, seemed to be rectimarginate. Mantle canal markings not seen. Both valves slightly corroded and worn, no sculpture or shell remains preserved. Specimen J 2020.593.1 is partly covered by shell with a thickness of $0.3-0.5 \mathrm{~mm}$. Lateral commissure strongly sinuous. Anterior commissure is partly destroyed but seems to be rectimarginate. Both valves show fine growth lines throughout from the umbo to the anterior commissure. Where it is not covered by shell remains, fine and thin imprints of vascular myarium channels are preserved on the right side of the dorsal valve internal mould.

Internal characters-Serial sectioning was not performed due to the paucity of the material (only one specimen).

Remarks. The present authors follow the opinion of Lee (2006) regarding the generic assignment for this species. Some authors (Vörös et al. 2019, 2020) consider that this species belong to Antinomia without further reasoning; however, according to Lee (2006: 2140), the latter one is a junior synonym for Pygope. Without established reasoning to place this species into Antinomia, we follow Lee (2006). Anyhow, its specific establishment is justified by Tubbs and Smith (1988: 373, Opinion No. 1466: specific name conserved). The specimen J 2020.591.1 is the closest to the specimen of Michalík (1996: fig. 3.9) with a large, erect ventral umbo and foramen and also specimen no. IGP 10,074 of Dieni and Middlemiss (1981: pl. 2, fig. 2); the only difference is that the Hungarian specimen has a larger ventral perforation closer to the anterior commissure. Almost all occurrences are reported from the Tithonian-Berriasian, however, the stratigraphic range of the species is much longer (Jarre 1962; Vörös et al. 2019). This asymmetric and obviously injured specimen (Fig. 8) survived the injury. This phenomenon is described separately from the taxonomic section and discussed later.

Stratigraphic and geographic distribution. This is the oldest pygopid brachiopod species among those with a perforation and it has a wide stratigraphic distribution. FO is in the upper Oxfordian (Jarre 1962: fig. 7). It is noteworthy, that Jarre (1962: 62) accepted Ficheur's (1891: 556) information when cited from Ficheur: "the beds that contain Terebratula catulloi at Ouarsenis [Algeria] are absolutely inseparable from the zone of Ammonites transversarius" [=Gregoryceras transversarium, index species of the Oxfordian Transversarium Zone]. Therefore, the Hungarian upper Oxfordian occurrence of this species strengthens the observation of Ficheur (1891) on the very early FO of Pygope catulloi. It ranges up to the lower Valanginian (Vörös et al. 2019, 2020) with an acme in the lower Tithonian when it reached its largest geographic distribution along both the northern and southern margins of the Western Tethys. 


\section{Discussion}

The appearance of pygopid brachiopods in the upper Oxfordian strata of the Mecsek Mountains is quite remarkable, however, not unique. Mediterranean influence took over in ammonite faunas during the Bathonian/Callovian (Galácz 1984) and is also reflected in Bathonian brachiopod faunas (Vörös 1990, 1995). The truly Mediterranean Jurassic of Sicily is described in detail by Jenkyns and Torrens (1971) who reported Bositra beds together with brachiopods in addition to the Middle Jurassic. These brachiopods are few, stunted and co-occur with Bositra shells (Jenkyns and Torrens 1971: 97, table 1). Vadász (1935: 61) mentioned a Posidonomya cf. alpina (Gras) from the Oxfordian of the Mecsek Mountains, but also collected from other localities (Óbánya, Ófalu and Pécsvárad) in the eastern part of the Mecsek Mountains. Based on the hinge structure, Posidonomya alpina is considered the same as Bositra buchi (Roemer) and was synonymized with it by Jefferies and Minton (1965) being accepted by other authors (cf. Jenkyns and Torrens 1971; Birkenmajer 2008). Bositra buchi is common from the Aalenian to Kimmeridgian (Delvene 2002) in ammonitico rosso facies of the Mediterranean Tethys (Conti and Monari 1992) having had a nektoplanktonic mode of life (Jefferies and Minton 1965). This result was conquered by Etter (1996) recently, returning to the benthic mode of life. This was considered a convincing evidence by Waller and Stanley (2005) who considering Bositra a benthic but not (pseudo- or nekton) planktonic bivalve.

In western Sicily, pygopid brachiopods within ammonitico rosso facies are characteristic of the whole upper Jurassic (Jenkyns and Torrens 1971) and it is the same facies and age in the Mecsek Mountains. Obviously, pygopid brachiopods from the upper Oxfordian ammonitico rosso-type limestone strata of the Mecsek Mountains fit into this scheme, not surprising, having not previously been recorded.

\section{Remarks on the palaeoenvironment}

The first record of brachiopods (Nucleata and Pygope) presented herein indicates a deep-shallow bathyal environment and updates the previous brachiopod record of Vadász (1935: 61) who reported a Terebratulina cf. substriata Schl. [=Terebratulina (Cruralina) substriata Schlotheim] from the Oxfordian. Unfortunately, this specimen is lost (Vörös 1997). The latter species is considered a constituent of diverse brachiopod assemblages transitional from perireefal environments to the sandy subtidal zone (Heliasz and Racki 1980). That shallow environment is dominated by brachiopods ( $80 \%$ of the collected specimens, cf. Heliasz and Racki 1980: 182) while ammonites represent only $1.5 \%$ of the total number of specimens (Heliasz and Racki 1980).
Other results also support the shallow water environment for T. substriata (Fürsich et al. 2007; Grădinaru and Bărbulescu 1994). Pygopid and nucleatid brachiopods are considered indicators of relatively deep (? bathyal) water depth (Ager 1965: 169). Consequently, we may conclude that the presence of Nucleata bouei and Pygope catulloi in the upper Oxfordian of the Mecsek Mountains indicate relatively deep, low energy waters in a bathyal basin, with very little water movement on the sea floor. The occurrence of Terebratulina cf. substriata is considered to be a transported element reworked from a shallow water habitat into the bathyal basin.

Recent representatives of Dyscolioidea live at depths ranging from 500 to $2000 \mathrm{~m}$ being most abundant in from 900 to $1200 \mathrm{~m}$. They are considered relatives of the smooth Pliensbachian brachiopods of the former Mediterranean oceanic basin (Vörös 2005). This observation from today's oceanic basins supports the hypothesized bathyal habitat for pygopid brachiopods in the Oxfordian of the Mecsek Mountains.

\section{Palaeobiogeographical considerations}

The upper Jurassic is generally characterized by continuous global sea-level rise (Haq et al. 1987; Vérard et al. 2015). Although there would have been local deviations from the global trend, the invasion of Mediterranean ammonite forms is detected in Bathonian/Callovian bathyal sequences of the Mecsek Mountains (Galácz 1984). The distribution of phylloceratid and lytoceratid shells in the peri-Tethyan basins were taphonomically and ecologically controlled by regional changes of sea level as noted by Fernández-López and Meléndez (1996) for Bajocian ammonite faunas from Iberia.

This was not necessarily the case everywhere. In the shallow marine settings as Grădinaru and Bărbulescu (1994) indicated on Oxfordian brachiopods from Dobrogea (Moesian platform, Romania) a mix of NW European and Tethyan faunal elements occurred. The herein reported pygopid brachiopods seem to contradict previous records. The reported Nucleata and Pygope are considered typical representatives of the Tethyan deep-water Pygopidae, while Terebratulina (Cruralina) striatula is reported from the Submediterranean Province along the northern margin of Western Tethys (Alméras et al. 1997; Grădinaru and Bărbulescu 1994); also sub-Tethyan or Jura of Middlemiss (1979). This apparent contradiction could be resolved considering different habitats of these brachiopods or as a result of intervening depth control fueled by global sea level rise, rather than a veritable provincialism as Grădinaru and Bărbulescu (1994: 69) concluded. Therefore, the shallow marine Terebratulina striatula may refer to the original NW palaeogeographic position of the Mecsek tectonic unit (Géczy 1973), while the herein reported pygopid brachiopods refer to the oceanic influence 
of the Tethys driven by continuous sea level rise that had started by the beginning of the Middle Jurassic.

\section{Palaeopathological observations}

According to Jones (1982: 917), evidence of injury and subsequent healing in ancient brachiopods has been observed many times (Tchoumatchenco 1987; Taddei-Ruggiero 1991; Motchurova-Dekova 1995; Harper 2005; Harper et al. 2009; Vörös 2009; Hoel 2014). Here, we present further evidence for injury and subsequent healing. One specimen of Pygope catulloi (J 2020.593.1) is a pathologic individual. There is a 7-mm long and 5-mm wide, oval-shaped injury on the left part of the ventral valve, close to the perforation (Fig. 9a). The individual survived the injury, that had most probably affected the epithelial cells and retarded normal development as shown in Fig. 9b. Toward the anterior part of the shell, beyond the injury the left ventral valve became indented and concave as opposed to the normal convex and slightly inflated shape. Although the injury occurred on the ventral valve, it is remarkable that at the same length the dorsal valve on the side of the injury also became retarded. Figure 9c shows that before the injury both valves developed symmetrically but beyond the injury, toward the aperture the left side of both valves became retarded and less developed.

Nature of the injury-Smaller shaped and sized, serial injuries are reported from Ordovician brachiopods by Cameron (1969) from Waynesville, Ohio, USA who considered those injuries to be borings that are all concentrated close or along the commissure. This placement of the wormholes occurred because of the competition that might have occurred with the host for suspended matter in the water (Cameron 1969: 701). However, this is probably not the case here. The injury is not placed along the commissure, however, taking into consideration the special fluid flow through the central perforation of pygopids (Vogel 1966), it cannot be ruled out.

Growth distortion among brachiopods is also known (Jones 1982). In the case of the Paleozoic Atrypoidea, Jones (1982: 920) made a thorough analysis. His methodology is followed here regarding the possibilities to explain the shell damage in Pygope catulloi: (1) predation, (2) crowding, (3) diagenetic changes, (4) epibiota and (5) disruption of shell secretion. Although the evidence is sparse, it is worth considering some of these possibilities and determine the most probable cause.

Predation-Tasnádi-Kubacska (1962) and Vörös (2009) reported aberrant brachiopods (Securithyris adnethensis Suess, 1855) from the Pliensbachian of the Bakony Mountains (Hungary) and the considered the damage was the result of predators biting (Dentisignia) and injuring the brachiopod. But this is not likely in the present case. If predators had been responsible, the severity of damage should be far greater than it is (Jones 1982: 920; Vörös 2009: fig. $90 \mathrm{a}-\mathrm{c}$ ). Boring predation traces are far smaller, and the neat circular cross-sections more typical in the post-Albian and have been assigned to muricid gastropods (Harper and Wharton 2000). Therefore, predation is not likely the cause of the injury. Observations on shell breakages of recent brachiopods (Harper et al. 2019) also reflect that predators mainly attack the anterior margins (cf. Harper et al. 2019: fig. 4a-f) and left different shaped damages.

Crowding - Taking into consideration the solitary mode of life of pygopid brachiopods in a nutrient-poor bathyal environment, crowding could be excluded as a responsible factor of the damage. The reported cases of Convictisignia (Motchurova-Dekova 1995; Vörös 2009) present remarkably different deformations on the shells.

Diagenetic changes-The observed damage in Pygope catulloi specimen may have resulted from diagenetic processes. But this is also unlikely. Around the oval-shaped damage, there is a ring-like band that refers to the secretion of shell on the ventral valve on one hand, and on the other hand, the dorsal valve also recoiled at the corresponding length to the damage seen on the ventral valve. This double recoiling of both valves cannot be explained if diagenetic changes are considered a cause of the damage.

Epibiota-No kind of epibiota has been yet reported on pygopid brachiopods. This is surely related to their habitat, which is bathyal, where epibionts did not find adequate lifesustaining conditions. However, similar shaped and sized damages are known on brachiopod shells (Ruggiero and Raia 2014) from shallow marine Pleistocene sediments in Italy. These kind of epibiont injuries are concentrated either shallow marine or mud-dwelling brachiopods as TaddeiRuggiero and Bitner (2008) discussed for Cenozoic brachiopods. Therefore, this is also unlikely.

Disruption of shell secretion-Malfunctioning of the epithelial cells or their damage will lead to an interruption of shell growth (Jones 1982). It seems probable that damage to the epithelial cells was responsible for the growth defects in the Pygope catulloi individual. It is also possible that this damage could have been caused by a disease of some type related to the injury.

Regarding the possible cause of the injury, the bite marks of a predator is the most plausible. The bites occur only on the ventral valve, as the predator would have pinched the young animal then released.

\section{Conclusions}

The first description of Oxfordian brachiopods based on a new collection from the Mecsek Mountains, Hungary provides a foundation for any further palaeobiogeographic analysis for the upper Jurassic. The presence of Nucleata bouei 
and Pygope catulloi in the upper Oxfordian of the Jurassic sequence of the Mecsek Mountains strengthens earlier paleobiogeographic results from the Bathonian/Callovian that Mediterranean Tethyan influence became significant in the Mecsek Mountains. With the reported brachiopods herein, the presence of pygopid species in the Mecsek Mountains is now more complete from the Bathonian (Vörös 1995) to the Valanginian (Bujtor 2006) except for the Callovian and Kimmeridgian. It reflects a constant and strong Mediterranean influence over the Tisza microplate from the beginning of the late Jurassic to the Valanginian. The pathologic individual of Pygope catulloi provides a remarkable example of the subsequent healing of brachiopod shells after injury. The most probable type of injury would have been a Dentisignia. The presence of Pygope catulloi in the upper Oxfordian of the Mecsek Mountians strengthens the early observations of its Oxfordian FO from Algeria. It implies that pygopid brachiopods appeared very early in the periphery of the Western Tethys.

Acknowledgements Open access publication provided by University of Pécs (PTE). Our thanks are to Attila Vörös for his valuable suggestions and discussion on the early version of this paper. Thanks to the Biodiversity Heritage Library (https://www.biodiversitylibrary.org) for the free access of valuable, rare, original papers from the nineteenth century. We acknowledge the help of our volunteer supporters (Orsolya Vincze, Fülöp Szeveréd Bujtor, Adriel Ördög, and Dávid Ördög) with field work. Our special thanks are due to the reviewers, Michael Sandy and Donald A.B. MacFarlan for all their supportive and constructive remarks, which highly increased the quality of our paper. In addition, we highly appreciate the linguistic support of Michael Sandy that raised our English on high professional level. Thanks also to editor-in-chief Mike Reich for his precise editorial comments.

Funding Open access funding provided by University of Pécs.

Open Access This article is licensed under a Creative Commons Attribution 4.0 International License, which permits use, sharing, adaptation, distribution and reproduction in any medium or format, as long as you give appropriate credit to the original author(s) and the source, provide a link to the Creative Commons licence, and indicate if changes were made. The images or other third party material in this article are included in the article's Creative Commons licence, unless indicated otherwise in a credit line to the material. If material is not included in the article's Creative Commons licence and your intended use is not permitted by statutory regulation or exceeds the permitted use, you will need to obtain permission directly from the copyright holder. To view a copy of this licence, visit http://creativecommons.org/licenses/by/4.0/.

\section{References}

Ager, D.V. 1965. The adaptations of Mesozoic brachiopods to different environments. Palaeogeography, Palaeoclimatology, Palaeoecology 1: 143-172. https://doi.org/10.1016/0031-0182(65)90011-8.

Alméras, Y., A. Boullier, and B. Laurin. 1997. Brachiopodes. In Biostratigraphie du Jurassique ouest-européen et méditerranéen. Zonations parallèles et distribution des invertébrés et microfossioles, eds. E. Cariou, and P. Hantzpergue. Groupe français d'Étude du Jurassique, Mémoire 17: 169-195.

Barczyk, W. 1991. Succession of the Tithonian to Berriasian brachiopod faunas at Rogoźnik, Pieniny Klippen Belt. Acta Geologica Polonica 41(12): 101-107.

Basse, E. 1930. Contribution fi l'étude du Jurassique supérieur (Facies Corallien) en Ethiopie et en Arabie méridionale. Mémoires de la Société géologique de France (Nouvelle Série) 6(3-4): 105-148.

Benzaggagh, M., F. Cecca, and I. Rouget. 2010. Biostratigraphic distribution of ammonites and calpionellids in the Tithonian of the internal Prerif (Msila area, Morocco). Paläontologische Zeitschrift 84: 301-315. https://doi.org/10.1007/ s12542-009-0045-1.

Birkenmajer, K. 2008. The Szopka Lime stone Formation - a new lithostratigraphic name for Upper Liassic beds of the Pieniny and Branisko successions, Pieniny Klippen Belt (West Carpathians). Studia Geologica Polonica 131: 229-235.

Böckh, J. 1880. Adatok a Mecsekhegység és dombvidéke jurakorbeli lerakodásainak ismeretéhez. I. Stratigraphiai rész. Értekezések a Természettudományok Köréból 10(10): 3-50.

Bujtor, L. 1993. Valanginian ammonite fauna from the Kisújbánya Basin (Mecsek Mts., South Hungary) and its palaeobiogeographical significance. Neues Jahrbuch für Geologie und Paläontologie, Abhandlungen 188(1): 103-131.

Bujtor, L. 2006. Early Valanginian brachiopods from the Mecsek Mts. (southern Hungary) and their palaeobiogeographical significance. Neues Jahrbuch für Geologie und Paläontologie, Abhand lungen 241(1): 111-152. https://doi.org/10.1127/njgpa/241/2006/ 111.

Bujtor, L., R. Albrecht, Cs. Farkas, B. Makó, D. Maróti, and Á Miklósy. subm. Kimmeridgian and Early Tithonian cephalopods from the Kisújbánya Limestone Formation, Zengővárkony (Mecsek Mountains, southern Hungary), their faunal composition, palaeobiogeographic affinities and taphonomic character. Carnets de Géologie.

Bujtor, L., R. Albrecht, D. Maróti, and Á. Miklósy. 2020. Lower Tithonian and lower Berriasian brachiopods from the Márévár Limestone Formation, Zengővárkony (Mecsek Mountains Hungary), and remarks on their palaeoenvironment. PalZ: Paläontologische Zeitschrift. https://doi.org/10.1007/s12542-020-00513-y.

Cameron, B. 1969. Paleozoic shell-boring annelids and their tracefossils. American Zoologist 9: 689-703. http://www.jstor.org/ stable/3881669

Catullo, T.A. 1827. Saggio di zoologia fossile ovvero osservazioni sopra li petrefatti delle provincie Austro-Venete con la descrizione dei Monti Entro ai quali si trovano, 1-348. Padova: Tipografia del Seminario.

Catullo, T.A. 1851. On the Epiolitic Rocks of the Venetian Alps. Geological Society of London, Quarterly Journal 7: 66-76.

Cohen, K.M., S.C. Finney, P.L. Gibbard, and J.-X. Fan. 2013. The ICS International Chronostratigraphic Chart. Episodes 36: 199-204. https://doi.org/10.18814/epiiugs/2013/v36i3/002.

Conti, A.M., and S. Monari. 1992. Thin-shelled bivalves from the Jurassic Rosso Ammonitico and Calcari a Posidonia formations of the Umbrian-Marchean Apennine (Central Italy). Palaeopelagos 2: 193-213.

Coquand, H. 1880. Description géologique et paléontologique de la région Sud de la province de Constantine. Études supplémentaires sur la Paléontologie Algérienne. Bulletin de l'Académie d'Hippone 15: 1-450.

Császár, G., B. Szinger, and O. Piros. 2013. From continental platform towards rifting of the Tisza Unit in the Late Triassic to Early Cretaceous. Geologica Carpathica 64: 279-290. https://doi.org/ 10.2478/geoca-2013-0020.

Csontos, L., and A. Vörös. 2004. Mesozoic plate tectonic reconstruction of the Carpathian region. Palaeogeography, Palaeoclimatology, 
Palaeoecology 210: 1-56. https://doi.org/10.1016/j.palaeo.2004. 02.033 .

Delvene, G. 2002. Revisión histórica de las especies bivalvos citadas en el Jurásico de la Cordillera Ibérica, España. Revista Española de Paleontología 17(2): 199-210.

Dieni, I., and F. Middlemiss. 1981. Pygopid brachiopods from the Venetian Alps. Bollettino della Societá Paleontologica Italiana 20(1): 19-48.

Douvillé, H. 1879. Note sur quelques genres de Brachiopodes. Bulletin de la Société géologique de France (3e série) 7: 251-267.

Duméril, A.M.C. 1806. Zoologie analytique, ou méthode naturelle de classification des animaux, rendue plus facile à l'aide de tableaux synoptiques, $\mathrm{i}-\mathrm{xxxiii}+1-344$. Paris: Allais.

Etter, W. 1996. Pseudoplanktonic and benthic invertebrates in the Middle Jurassic Opalinum Clay, northern Switzerland. Palaeogeography, Palaeoclimatology, Palaeoecology 126(3-4): 325-341. https://doi.org/10.1016/S0031-0182(96)00036-3.

Favre, E. 1875. Description des fossiles du terrain Jurassique de la Montagne Voirons (Savoie). Mémoires de la Société Paléontologique Suisse 2: 1-79.

Favre, E. 1877. La zone a Ammonites acanthicus dans les Alpes de la Suisse et de la Savoie. Mémoires de la Société Paléontologique Suisse 4: 1-114.

Fernández-López, S., and G.H. Meléndez. 1996. Phylloceratina ammonoids in the Iberian Basin during the Middle Jurassic: a model of biogeographical and taphonomic dispersal related to relative sea-level changes. Palaeogeography, Palaeoclimatology, Palaeoecology 120: 291-302. https://doi.org/10.1016/0031-0182(95) 00046-1.

Ficheur, E. 1891. Sur la situation des couches à Terebratula diphya dans l'Oxfordien supérieur à l'Ouarsenis (Algérie). Bulletin de la Société géologique de France (3e série) 19: 556-563.

Fischer, P., and D.-P. Oehlert. 1891. Brachiopodes. In Expéditions scientifiques du 'Travailleur' et du 'Talisman' (1880-1883), ed. E. Milne-Edwards, i-viii + 1-139. Paris: Masson.

Főzy, I. 1993. Upper Jurassic ammonite biostratigraphy of the Mecsek Mts., Hungary. Földtani Közlöny 123(2): 195-205.

Főzy, I., ed. 2012. Magyarország litosztratigráfiai alapegységei. Jura. Budapest: Magyarhoni Földtani Társulat.

Fülöp, J. 1964. Unterkreide-Bildungen (Berrias-Apt) des BakonyGebirges. Geologica Hungarica series Geologica 13: 1-194.

Fülöp, J., G. Hámor, R. Hetényi, and G. Vigh. 1960. Über die Jurabildungen des Vértesgebirges. Földtani Közlöny 90(1): 15-26.

Fürsich, F.T., W. Werner, S. Schneider, and M. Mäuser. 2007. Sedimentology, taphonomy, and palaeoecology of a laminated plattenkalk from the Kimmeridgian of the northern Franconian Alb (southern Germany). Palaeogeography, Palaeoclimatology, Palaeoecology 243: 92-117. https://doi.org/10.1016/j. palaeo.2006.07.007

Galácz, A. 1984. Jurassic of Hungary: a review. Acta Geologica Hungarica 27(3-4): 359-377.

Galácz, A. 2015. Macrocephalitid-bearing Lower Callovian (Middle Jurassic) beds in the Mecsek Mts (South Hungary). Hantkeniana 10: 73-88.

Géczy, B. 1973. Plate tectonics and paleogeography in the East-Mediterranean Mesozoic. Acta Geologica Academiae Scientiarum Hungaricae 17(4): 421-428.

Géczy, B. 1984. Provincialism of Jurassic ammonites; examples from Hungarian faunas. Acta Geologica Hungarica 27(3-4): 379-389.

Grădinaru, E., and A. Bărbulescu. 1994. Upper Jurassic brachiopod faunas of Central and North Dobrogea (Romania): biostratigraphy, paleoecology and paleobiogeography. Jahrbuch der Geologischen Bundesanstalt 137(1): 43-84.
Haas, J., and Cs. Péró. 2004. Mesozoic evolution of the Tisza Megaunit. International Journal of Earth Sciences 93(2): 297-313. https://doi.org/10.1007/s00531-004-0384-9.

Haq, B., J. Hardenbol, and P. Vail. 1987. Chronology of fluctuating sea levels since the Triassic. Science 235: 1156-1167.

Harper, E.M. 2005. Evidence of predation damage in Pliocene Apletosia maxima (Brachiopoda). Palaeontology 48(1): 197-208. https://doi.org/10.1111/j.1475-4983.2004.00433.x.

Harper, E.M., and D. Wharton. 2000. Boring predation and Mesozoic articulate brachiopods. Palaeogeography, Palaeoclimatology, Palaeoecology 158(1-2): 15-24. https://doi.org/10.1016/ S0031-0182(99)00164-9.

Harper, E.M., L.S. Peck, and K.R. Hendry. 2009. Patterns of shell repair in articulate brachiopods indicate size constitutes a refuge from predation. Marine Biology 156: 1993-2000. https:// doi.org/10.1007/s00227-009-1230-1.

Harper, E.M., M.D. Lamare, and D.E. Lee. 2019. Patterns of unrepaired shell damage in Recent brachiopods from Fiordland (New Zealand). Rivista Italiana di Paleontologia e Stratigrafia 125(3): 669-677.

Heliasz, Z., and G. Racki. 1980. Ecology of the Upper Jurassic brachiopod bed from Julianka, Polish Jura Chain. Acta Geologica Polonica 30(2): 175-197.

Hetényi, R., G. Hámor, and I. Nagy. 1968. Magyarázó a Mecsek hegység földtani térképéhez 10 000-es sorozat. Budapest: Magyar Állami Földtani Intézet.

Hoel, O.A. 2014. Palaeobiology of Silurian Leptaeninae (Brachiopoda) from Gotland, Sweden. Palaeontology Journal 2014: 716053. https://doi.org/10.1155/2014/716053.

Jarre, P. 1962. Révision du genre Pygope. Géologie Alpine 38: 23-120.

Jefferies, R.P.S., and P. Minton. 1965. The mode of life of two Jurassic species 'Posidonia' (Bivalvia). Palaeontology 8(1): $156-185$.

Jenkyns, H.C., and H.S. Torrens. 1971. Palaeogeographic evolution of Jurassic seamounts in western Sicily. Annales Instituti Geologici Publici Hungarici 54(2): 91-104.

Jones, B. 1982. Paleobiology of the Upper Silurian brachiopod Atrypoidea. Journal of Paleontology 56(4): 912-923. https://www. jstor.org/stable/1304710

Kázmér, M. 1990. Tithonian-Neocomian palaeogeography of Pygopidae (Brachiopoda) in the Alpine-Carpathian region. Általános Földtani Szemle 25: 327-335.

Kázmér, M. 1993. Pygopid brachiopods and Tethyan margins. In Mesozoic brachiopods of Alpine Europe, eds. J. Pálfy and A. Vörös, 59-68. Budapest: Hungarian Geological Society.

Lee, D.E. 2006. Dyscolioidea. In Treatise on Invertebrate Paleontology Part H Brachiopoda Revised Volume 5: Rhynchonelliformea (part). ed. R.L. Kaesler, 2136-2144. Boulder, Colo.: The Geological Society of America, and Lawrence, Kans.: The University of Kansas.

Link, H.F. 1830. Handbuch der physikalischen Erdbeschreibung, Theil 2: Abth 1. i-vi + 1-498. Berlin: Dümmler.

Lobatscheva, S.V. 1983. On the Berriasian brachiopods of Crimea. Yearbook of the All-Union Palaeontological Society 26: 184-206 (in Russian).

Lukeneder, A. 2002. Shell accumulation of the brachiopod Pygope catulloi Pictet, 1867 (Lower Valanginian; Northern Calcareous Alps, Upper Austria): Palaeoecological implications. Annalen des Naturhistorisches Museums in Wien (Serie A) 103: 143-159.

Manceñido, M.O. 1993. First record of Jurassic nucleatid brachiopods from the southwest Pacific with comments on the global distribution of the group. Palaeogeography, Palaeoclimatology, Palaeoecology 100(1-2): 189-207. https://doi.org/10.1016/ 0031-0182(93)90042-H. 
Michalík, J. 1996. Functional morphology - paleoecology of pygopid brachiopods from the Western Carpathian Mesozoic. In Brachiopods. Proceedings of the Third International Brachiopod Congress, eds. P. Copper, and J. Jin, 175-178. Rotterdam: A.A. Balkema Publishers.

Middlemiss, F.A. 1979. Boreal and Tethyan brachiopods in the European Early and Middle Cretaceous. International Union of Geological Sciences (Ser. A) 6: 351-361.

Mišík, M., M. Siblík, M. Sỳkora, and R. Aubrecht. 1994. Jurassic brachiopods and sedimentological study of the Babiná klippe near Bohunice (Czorsztyn Unit, Pieniny Klippen Belt). Mineralia Slovaka 26: 255-266.

Motchurova-Dekova, N. 1995. Paleoecologic and taphonomic notes on the localities of Late Cretaceous rhynchonellids (Brachiopoda) in Bulgaria. Review of the Bulgarian Geological Society 56(1): 47-60.

Muir-Wood, H.M. 1965. Mesozoic and Cenozoic Terebratulidina. In Treatise on Invertebrate Paleontology, Part H, Brachiopoda, ed. R.C. Moore, 762-816. New York, N.Y.: Geological Society of America and Lawrence, Kans.: University of Kansas Press.

Nagy, I. 1964. A Zengővárkonynál feltárt malm rétegösszlet mikrobiofácies-vizsgálata. A Magyar Állami Földtani Intézet Évi Jelentése az 1961(I): 97-108.

Nagy, I. 1971. Subdivision of the Upper Jurassic beds of the Mecsek Mountains based on fossil organisms. A Magyar Állami Földtani Intézet Évkönyve 54(2): 319-332. (in Russian).

Oppel, A. 1860. Ueber die weissen und rothen Kalke von Vils in Tyrol. Jahreshefte des Vereins für vaterländische Naturkunde Wuerttemberg 17: 129-168.

Peters, K.F. 1862. Über den Lias von Fünfkirchen. Sitzungsberichte der Kaiserlichen Akademie der Wissenschaften in Wien (Mathematisch-Naturwissenschaftliche Klasse) 46: 241-293.

Pictet, F.-J. 1867. Étude monographique des térébratulés du groupe de la T. diphya. Mélanges paléontologiques 3: 135-184.

Quenstedt, F.A. 1868-1871. Petrefactenkunde Deutschlands, Abtheilung 1, Band 2: Die Brachiopoden, i-iv + 1-748. Leipzig: Fues.

Ruggiero, E., and P. Raia. 2014. Oichnus taddeii, a new fossil trace produced by capulids on brachiopod shells. Spanish Journal of Palaeontology 29(1): 15-24. https://doi.org/10.7203/sjp.29.1.17484.

Sandy, M.R. 1988. Tithonian Brachiopoda. In Evolution of the Northern Margin of Tethys, vol. I, eds. M. Rakus, J. Dercourt, and A.E.M. Nairn. Mémoires de la Société Géologique de France (Nouvelle Série) 154: 71-74.

Schlotheim, E.F. von. 1820. Die Petrefactenkunde auf ihrem jetzigen Standpunkte durch die Beschreibung seiner Sammlung versteinerter und fossiler Überreste des Thier- und Pflanzenreiches der Vorwelt erläutert, i-1xii + 1-437. Gotha: R.Z. Becker.

Schuchert, C. 1929. Classification of brachiopod genera, Fossil and Recent. In Brachiopoda (Generum et Genotyporum Index et Bibliographia), C. Schuchert, and C.M. LeVene. Fossilium Catalogus (1: Animalia) 42: 10-25.

Sequeiros, L. 1977. Nuevos datos paleontológicos y bioestratigráficos de Glossothyris (Brachiopoda, Terebratulidae) en la zona subbética (España meridional). Acta Geológica Hispánica 12(1-3): 8-11.

Somody, Á. 1992. Paleobiogeographic relationships of the Early Cretaceous brachiopods of the Bakony Mts. in the Alpine-Carpathian region. Discussiones Palaeontologicae 38: 107-119.

Sulser, H. 2016. Die Brachiopoden der Klippendecke (Préalpes médianes) in den Préalpes romandes der Südwestschweiz, des Chablais und der zentralschweizerischen Klippen: eine Übersicht und paläogeographische Beziehungen. Revue de Paléobiologie 35(2): 385-416.

Taddei-Ruggiero, E. 1991. A study of damage evidence in brachiopod shell, 203-210. In Brachiopods through time, eds. D.I.
MacKinnon, D.E. Lee, and J.D. Campbell, 203-210. Rotterdam: Balkema.

Taddei-Ruggiero, E., and A.M. Bitner. 2008. Bioerosion on brachiopod shells - a Cenozoic perspective. Earth and Environmental Science Transactions of the Royal Society of Edinburgh 98: 369-378. https://doi.org/10.1017/S1755691007080371.

Tari, G. 2015. The palinspastic position of Tisia (Tisza) in the Alpine realm: a view from the outside of the Pannonian Basin. In Tisia Conference 27-28 February, 2015, Pécs, eds. V. Dályay and M. Sámson, 29-32. Pécs: Molnár Nyomda és Kiadó.

Tasnádi-Kubacska, A. 1962. Paläopathologie 1: Pathologie der vorzeitlichen Tiere, 1-269. Jena: G. Fischer.

Tchorzhevsky, E.S. 1989. O iurskikh terebratulidakh Nucleatidae (brakhiopody)/On the Jurassic terebratulids Nucleatidae (brachiopods). Paleontologicheskii Zhurnal 1989(4): 25-36. (in Russian).

Tchoumatchenco, P.V. 1987. Vivisignia - ichnofossils on shells of Bulgarian Lower Jurassic brachiopods. Geologica Balcanica 17(4): $79-81$.

Thieuloy, J.-P. 1963. Nouveaux apports á la faune Tithonique du Col du Lauzon (Hautes-Alpes). Géologie Alpine 39: 283-302.

Toucas, A.M. 1890. Étude de la Faune des couches tithoniques de l'Ardéche. Bulletin de la Société géologique de France (Sér. 3) 18: 560-629.

Tubbs, P.K., and J.D.D. Smith. 1988. Notice. Bollettino di Zoologia 55(1-4): 99-374. https://doi.org/10.1080/11250008809386637.

Vadász, E. 1935. A mecsekhegység / Das Mecsek-Gebirge. Magyar tájak földtani leirása / Geologische Beschreibung Ungarischer Landschaften I: 1-180 + i-xxv.

Vérard, C., C. Hochard, P.O. Baumgartner, and G.M. Stampfli. 2015. 3D palaeogeographic reconstructions of the Phanerozoic versus sea-level and Sr-ratio variations. Journal of Palaeogeography 4(1): 64-84. https://doi.org/10.3724/SP.J.1261.2015.00068.

Vogel, K. 1966. Eine funktionsmorphologische Studie an der Brachiopodengattung Pygope (Malm bis Unterkreide). Neues Jahrbuch für Geologie und Paläontologie, Abhandlungen 125: 423-442.

Vörös, A. 1990. Distribution of Lower and Middle Jurassic brachiopods: data to the palaeogeographical evaluation of the AlpineCarpathian area. Általános Földtani Szemle 25: 251-263.

Vörös, A. 1993. Jurassic microplate movements and brachiopod migrations in the western part of the Tethys. Palaeogeography, Palaeoclimatology, Palaeoecology 100: 125-145. https://doi.org/10. 1016/0031-0182(93)90037-J.

Vörös, A. 1995. Bathonian brachiopods of the Mecsek Mts Hungary. Annales Universitatis de Rolando Eötvös nominate Scientorum Budapestinensis sectio Geologica 30(181-208): 237-238.

Vörös, A. 1997. Jurassic brachiopods of Hungary. Faunal changes and paleobiogeography in the Western Tethys. Studia Naturalia 11: $1-110$.

Vörös, A. 2005. The smooth brachiopods of the Mediterranean Jurassic: Refugees or invaders? Palaeogeography, Palaeoclimatology, Palaeoecology 223: 222-242. https://doi.org/10.1016/j.palaeo. 2005.04.006.

Vörös, A. 2009. The Pliensbachian brachiopods of the Bakony Mountains (Hungary). Geologica Hungarica series Palaeontologica 58: $1-300$.

Vörös, A., and A. Dulai. 2007. Jurassic brachiopods of the Transdanubian Range (Hungary); stratigraphical distribution and diversity changes. Fragmenta Palaeontologica Hungarica 24-25: 51-68.

Vörös, A., I. Főzy, and O. Szives. 2019. Brachiopod distribution through the Jurassic-Cretaceous transition in the western Tethyan pelagic realm: Example from the Bakony Mountains, Hungary. Cretaceous Research 104: 104182. https://doi.org/10.1016/j.cretr es.2019.07.012.

Vörös, A., I. Fôzy, A. Dulai, and O. Szives. 2020. Late Valanginian extinction and turnover of Tethyan brachiopods: A signal of the Weissert Event (Bakony Mountains, Hungary). Palaeogeography, 
Palaeoclimatology, Palaeoecology 555: 109856. https://doi.org/ 10.1016/j.palaeo.2020.109856.

Waagen, W.H. 1883. Salt-Range fossils Volume I. Part 4. Productus Limestone fossils, Brachiopoda. Memoirs of the Geological Survey of India, Palaeontologia Indica (series 13) 2: 391-546.

Waller, W.R., and G.D. Stanley jr. 2005. Middle Triassic Pteriomorphian Bivalvia (Mollusca) from the New Pass Range, West-Central Nevada: systematics, biostratigraphy, paleoecology, and paleobiogeography. The Paleontological Society Memoir 61: 1-64.

Williams, A., S. Carlson, C.H.C. Brunton, L.E. Holmer, and L.E. Popov. 1996. A supra-ordinal classification of the Brachiopoda.
Philosophical Transactions of the Royal Society, Biological Sciences 351: 1117-1193.

Zejszner, L. 1846. Nowe lub niedoktadnie opisane Gatunki skamieniałości Tatrowych / New and little-known described genera of fossils from the Tatra Mountains, 1-32. Warszawa: S. Strabskiego. (in Polish).

Zittel, K. 1870. Die Fauna der aeltern Cephalopodenfuehrenden Tithonbildungen. Palaeontographica, Supplement SII(1): 1-192. 